\title{
PHYTOPLANKTON DIVERSITY AS A RESPONSE OF WATER QUALITY IN RIVER NILE QENA, EGYPT
}

\author{
Abla A.M. Farghl ${ }^{{ }^{*}}$ and Asmaa A. Samer ${ }^{2}$ \\ ${ }^{1}$ South Valley University, Faculty of Science, Botany Department, Qena, Egypt \\ ${ }^{2}$ Holding Company of Water and Wastewater, Qena, Egypt
}

\begin{abstract}
Changes in phytoplankton density and its relation to physico-chemical nature of the River Nile water were monitored from March 2010 to February 2011 from six sampling sites along the River Nile at Qena, Governorate, Egypt. Physico-chemical parameters: temperature, $\mathrm{pH}, \mathrm{DO}, \mathrm{COD}$, turbidity and nutrients were measured. Eighty three species have identified during the study belong to five divisions of phytoplankton. Chlorophyta was the predominant group by 36 species followed by Bacillariophyta (diatoms) (33sp.), Cyanophyta (11sp.), Dinophyta (2sp.) and Euglenophyta (1sp.). Phytoplankton density ranged from 2597 to $5227 \mathrm{org}$. $\mathrm{ml}^{-1}$ along the study period. Also, chlorophyll a content as indicator of algal growth and trophic state are ranged between 2.31 and $26.05 \mu \mathrm{g} \mathrm{L}^{-1}$ along the study period. Statistical analysis showed that positive correlation of total algal counts with $\mathrm{pH}$, turbidity, DO and Chl.a. Furthermore, a pronounced correlation was detected between silica concentration and diatoms count.
\end{abstract}

Keywords: Algal count, Chlorophyll"a", Phytoplankton, River Nile, Water quality.

\section{Introduction}

The River Nile is the life artery of Egypt. Throughout the known Egyptian history, the Nile had dominating influences on the economy, culture, public health, social life and political aspects (Abdel-Hamid et al., 1992).

River Nile is the main source of potable water for Egypt. After High Dam construction generally is held long enough to permit significant changes in physical, chemicals and biological characteristics of water (Fishar and Khalifa, 2003).

According to the National Water Research Center (NWRC, 2000), the River Nile from Aswan to El-Kanater Barrage receives wastewater discharge from 124 point sources, of which 67 are agricultural drains and the remainders are industrial sources. 
Physical factors that influence the type and numbers of phytoplankton in the river are flow rate, light, water level, temperature and turbidity. Biologically, temperature and solar radiation occupy an important role in the control of planktonic life. Temperature changes not only affect physiological processes of cells, but also influence the kind of life that present in water (Abo El-lil, 2003). Garret et al. (1970) found that temperature was the major factor influencing both algal growth and phosphorus removal. The $\mathrm{pH}$ of a water body is very important in determination of water quality since it affects other chemical reactions such as solubility and metal toxicity (Amer and Abd El-Gawad, 2012). Dissolved Oxygen (DO) content, plays a vital role in supporting aquatic life and is susceptible to slight environment changes. Oxygen depletion often occurs during times of high community respiration. Hence, DO have been extensively used as a parameter delineating water quality and to evaluate the degree of freshness of a river (Hassan et al., 2010).

The main objectives of this research are studying the changes in phytoplankton distribution pattern and relation to physico-chemical properties of the River Nile water at Qena district.

\section{Materials and Methods}

Study area: Subsurface water samples were collected from the main sources of drinking water in River Nile, Egypt. Study area of the Nile is located at Qena district along a $60 \mathrm{Km}$. Six sampling sites were chosen (Fig.1) as follows:

Site $_{\mathrm{I}}\left(\mathbf{S}_{\mathbf{I}}\right)=$ intake of Al-Hemadat water works

Site $_{\text {II }}\left(\mathbf{S}_{\text {II }}\right)=$ intake of Al-Waqf water works

Site $_{\text {III }}\left(\mathbf{S}_{\text {III }}\right)=$ intake of Al-ALumium water works

Site $_{\text {IV }}\left(\mathbf{S}_{\text {IV }}\right)=$ intake of Naga - Hammady water works (Befor Naga-

Hammady sugar company)

Site $_{\mathbf{V}}\left(\mathbf{S}_{\mathbf{V}}\right)=$ in front of Naga-Hammady sugar company

Site $_{\mathrm{VI}}\left(\mathbf{S}_{\mathrm{VI}}\right)=$ Al-derb (After Naga-Hammady sugar company)

Water Analysis: Water samples were collected monthly (from March 2010 to February 2011). Temperature and the $\mathrm{pH}$ values of water were determined in the 
field by thermometer and the electric $\mathrm{pH}$ meter (Handylab pH11/set, SCHOTT instruments, Germany), respectively. Other physico-chemical parameters of water (Turbidity, dissolved oxygen, chemical oxygen demand, ammonia, nitrite, silica, iron and manganese were determined according to the standard methods, recommended by the APHA, 2005. In addition, nitrate and phosphate were determined using the methods of Gales et al. (1966).

Phytoplankton analysis: Nile water algae were identified according to Hindak $\boldsymbol{e t}$ al., (1975) and counted using compound microscope (Leica DM500). Chlorophyll a values were measured according to standard method (APHA, 1992). Diversity index was performed according to Shannon and Weaver (1963).

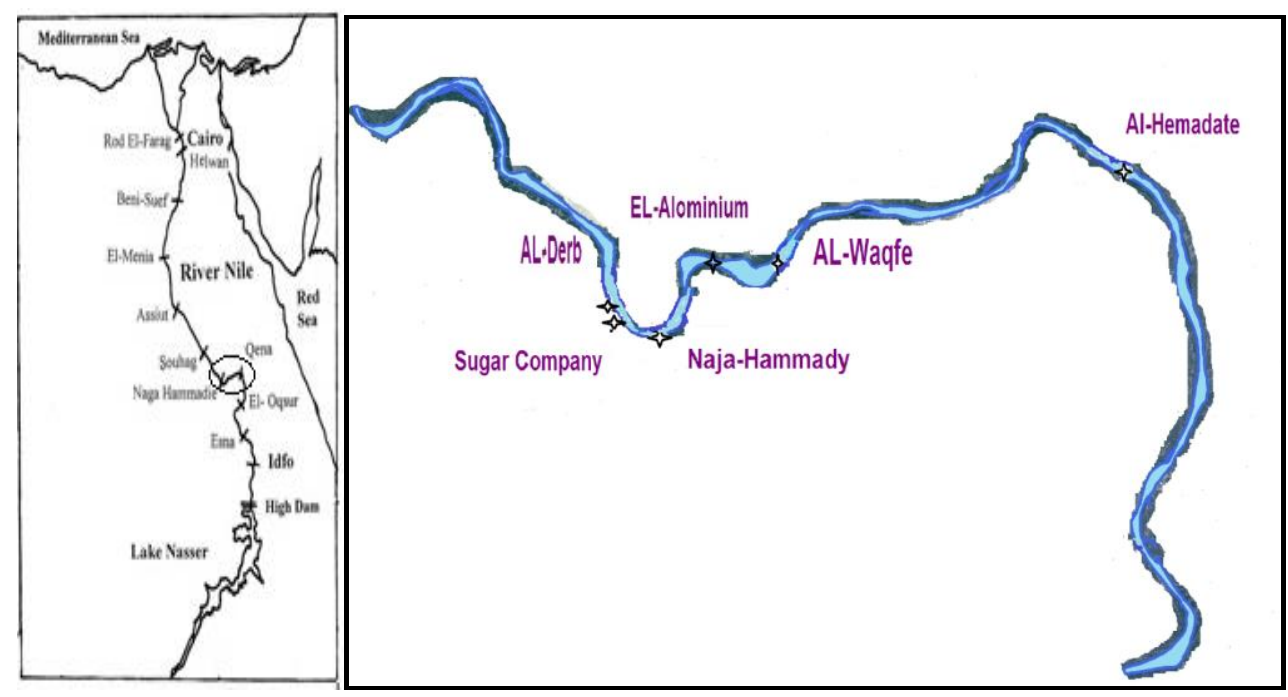

Fig. 1: Location map of the River Nile showing sampling sites.

Statistical Analysis: Statistical analysis was established applying regression coefficient according to Challerjee and Machler, 1995. 


\section{Results and Discussion}

\section{Physico-chemical analysis of Nile water:}

Temperature: The temperature values ranged between 17.8 and $30.6{ }^{\circ} \mathrm{C}$ along the study period (Table1). Water temperature of River Nile plays an important role for the heat budget of the Nile water (Abdel-Satar, 2005). Temperature is a key factor which regulates River Nile phytoplankton population (Mohammed, et al. 1986; Abd El-Hady, 2014). Temperature showed negative correlation with $\mathrm{pH}$ value, dissolved oxygen and phytoplankton counts (Table 2). Similar results were obtained by Sharma et al. (2008) who found that, temperature showed negative correlation with DO $(=-0.9)$ in Narmada River, India.

Table 1: Annual range of River Nile water characters during March 2010February 2011.

\begin{tabular}{|lcccccc|}
\hline Parameters & Site I & Site II & Site III & Site IV & Site V & Site VI \\
\hline Temperature ${ }^{\circ} \mathrm{C}$ & $19.60-30.10$ & $17.80-30.60$ & $18.30-29.00$ & $18.80-28.60$ & $18.80-28.20$ & $18.80-28.10$ \\
\hline PH & $8.00-8.57$ & $7.80-8.39$ & $8.00-8.59$ & $8.00-8.69$ & $8.00-8.85$ & $8.00-8.53$ \\
\hline $\begin{array}{l}\text { Turbidity } \\
\text { NTU }\end{array}$ & $1.00-4.00$ & $0.62-3.77$ & $1.40-5.34$ & $1.00-5.75$ & $0.93-3.95$ & $1.00-4.66$ \\
\hline DO \# & $5.00-7.50$ & $4.80-7.40$ & $5.30-8.30$ & $5.50-8.70$ & $5.20-8.80$ & $5.20-8.00$ \\
\hline COD \# & $7.20-13.70$ & $3.90-13.70$ & $5.50-23.39$ & $5.00-19.50$ & $3.30-17.80$ & $4.00-15.30$ \\
\hline Ammonia \# & Nil-0.27 & Nil -0.03 & Nil-0.40 & Nil-0.17 & Nil-0.13 & Nil-0.32 \\
\hline Nitrate \# & $0.13-1.00$ & $0.11-0.83$ & $0.15-1.61$ & $0.16-1.24$ & $0.18-1.18$ & $0.16-1.26$ \\
\hline Nitrite \# & Nil-0.09 & Nil-.01 & Nil-0.16 & Nil-0.08 & Nil-0.07 & Nil-0.15 \\
\hline Phosphate & Nil-0.01 & Nil-0.01 & Nil-0.05 & Nil-0.07 & Nil-0.04 & Nil-0.12 \\
\hline $\begin{array}{l}\text { Dissolved } \\
\text { Silica \# }\end{array}$ & $2.60-14.26$ & $1.66-12.00$ & $1.82-9.50$ & $1.46-10.40$ & $1.36-8.42$ & $1.38-12.40$ \\
\hline Iron \# & $0.05-0.33$ & $0.06-0.32$ & $0.09-0.39$ & $0.07-0.53$ & $0.04-0.25$ & $0.06-0.25$ \\
\hline Manganese \# & Nil-0.09 & Ni-0.06 & Nil-0.06 & Nil-0.08 & Nil-0.07 & Nil-0.08 \\
\hline \multicolumn{1}{c}{$*$ Nil=0 } & DO = Dissolved Oxygen & COD = Chemical Oxygen demand & $\#=$ mg L ${ }^{-1}$
\end{tabular}


The pH: The $\mathrm{pH}$ of the water of River Nile was alkaline (7.80-8.85). The highest value was associated with prevailing algae (Fig.2). Correlation analysis (Table 2) showed that positive correlation of $\mathrm{pH}$ with total algal counts $(\mathrm{r}=+$ 0.938), DO $(r=+0.754)$ and also Chl.a $(r=+0.883)$. Similar observation recorded by Shehata and Badr (2010) revealed that, $\mathrm{pH}$ showed positive correlation with DO $(r=+0.59)$ and total algal counts $(r=+0.65)$ in River Nile Cairo, Egypt. The increase in total phytoplankton counts was accompanied by an increase in $\mathrm{pH}$ values (Hammad and Ibrahim, 2012), this could be explained by Lai and Lam (1997) who mentioned that phytoplankton photosynthetic activity at surface water consumes carbon dioxide from the water, resulting in increasing $\mathrm{pH}$ values.
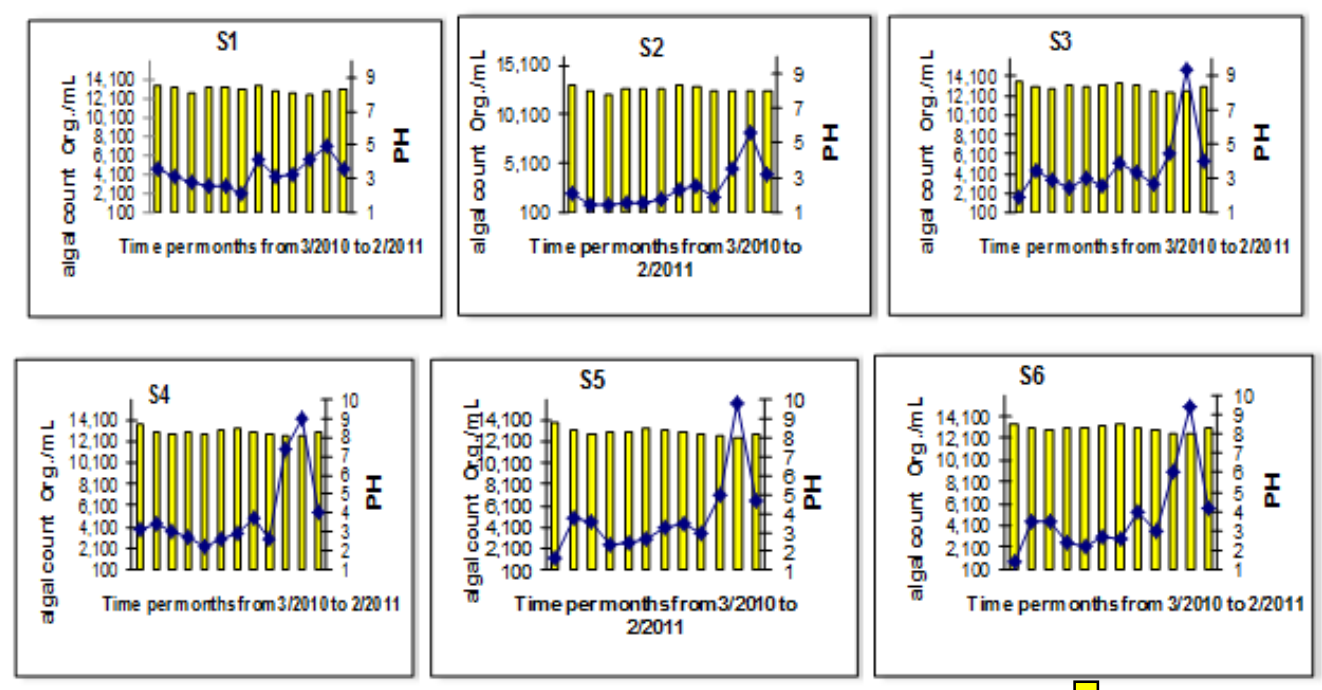

Fig. 2: Relationship between

total algal count $($ Org/ml $)$ and River Nile

PH Along

Turbidity: During the study there was an increase in turbidity values during autumn and winter months this may be due to flood and winter plug. Lowest turbidity value of $0.62 \mathrm{NTU}$ was recorded at $S_{\text {II }}$ and the highest value of 5.75 NTU at $S_{\text {IV }}$. Positive correlation was found between turbidity values and total algal counts (Fig.3). This confirmed by statistical analysis which $(\mathrm{r}=+0.618)$ between turbidity and total algal counts (Table 2) this is in agreement with Shehata and Badr (2010) observed that, turbidity showed positive correlation with total algal counts $(\mathrm{r}=+0.94)$ in River Nile Cairo, Egypt. 


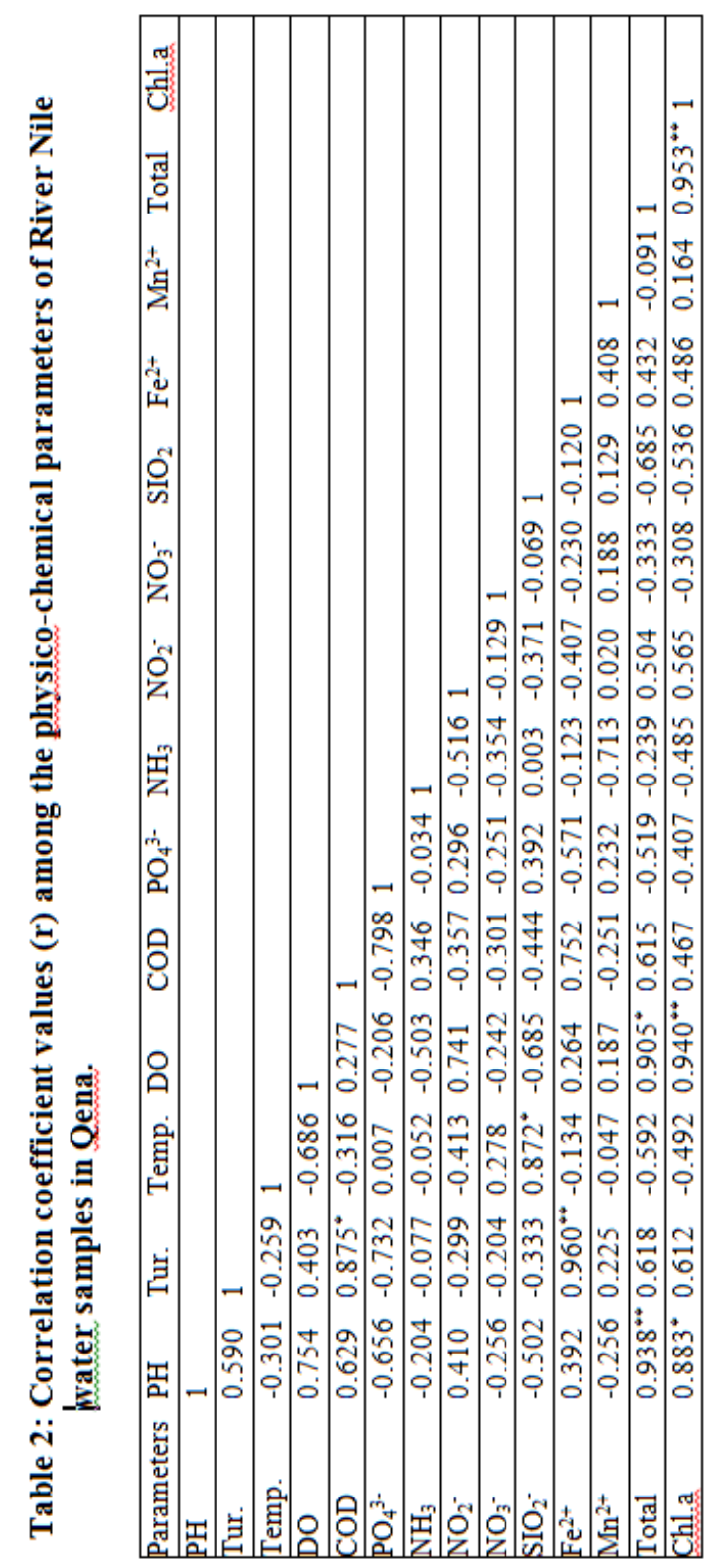

Egyptian J. of Phycol. Vol. 16, 2015 

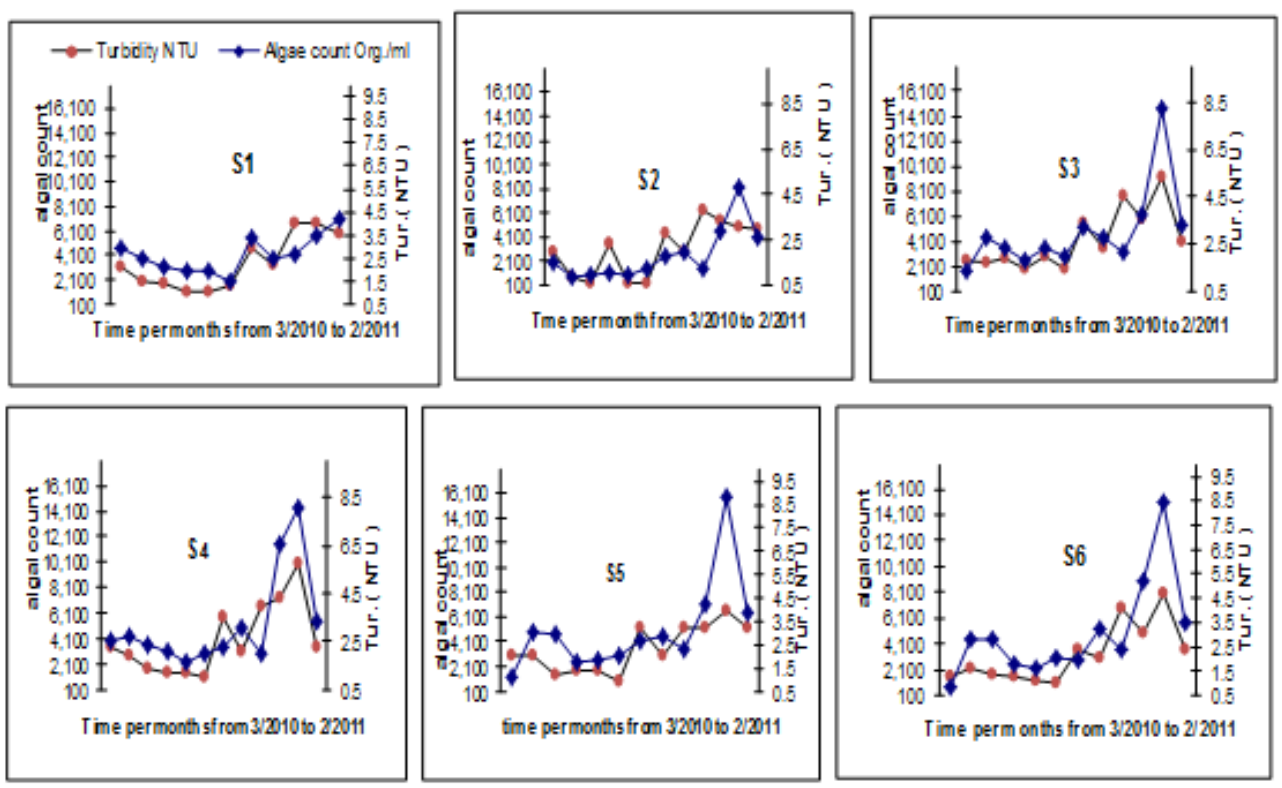

Fig. 3: Relationship between total algal count (Org/ml ) and turbdity along River Nile

Dissolved Oxygen (DO): Dissolved oxygen in natural water depends on the physical, chemical and biological activities in the water body. DO reach a maximum value of $8.80 \mathrm{mg} \mathrm{O}_{2} \mathrm{~L}^{-1}$ in December at $\mathrm{S}_{\mathrm{V}}$ and reached a minimum value of $4.80 \mathrm{mgO}_{2} \mathrm{~L}^{-1}$ in September at $\mathrm{S}_{\text {II }}$ (Fig.4). The WHO (world health organization 2004) suggested the standard of DO is $>5 \mathrm{mg} \mathrm{O} \mathrm{O}_{2} \mathrm{~L}^{-1}$. From a biological standpoint, the phytoplankton density in Nile water strongly influences the concentration of dissolved oxygen. High levels of dissolved oxygen were observed during winter months when phytoplankton especially those belonging to diatoms group were abundant (Figs.3\&6). DO showed positive correlation with total algal counts $(\mathrm{r}=+0.905), \mathrm{pH}(\mathrm{r}=+0.754)$ and nitrite $(\mathrm{r}=+0.741)$. Gharib and Abdel-Halim (2006) showed that, oxygen in Lake Nasser exhibits a positive correlation with phytoplankton abundance and phytoplankton biomass.

Chemical Oxygen Demand (COD): COD provides a measure of the oxygen equivalent to that portion of the organic matter in a sample that is susceptible to oxidation by a strong chemical oxidant. The maximum value of COD $(23.39 \mathrm{mg} \mathrm{L}$ 
${ }^{1}$ ) was recorded at $S_{\text {III }}$ and minimum value of $3.30 \mathrm{mg} \mathrm{L}^{-1}$ at $S_{\mathrm{V}}$ as show in (Table1). Most of recorded COD values exceeded the limit stated of Egyptian guide (Not exceed $10 \mathrm{mg} \mathrm{L}-1$ ) indicates presence of pollution at all investigated sites. The results are generally in agreement with these obtained by Abdel-Satar (2005) showed a pronounced increase in COD $\left(3.2-50.09 \mathrm{mg} \mathrm{L}^{-1}\right)$ in the riverbank water than the Midstream sites exceeding the Egyptian standard values for COD (10 mg $\left.\mathrm{L}^{-1}\right)$.
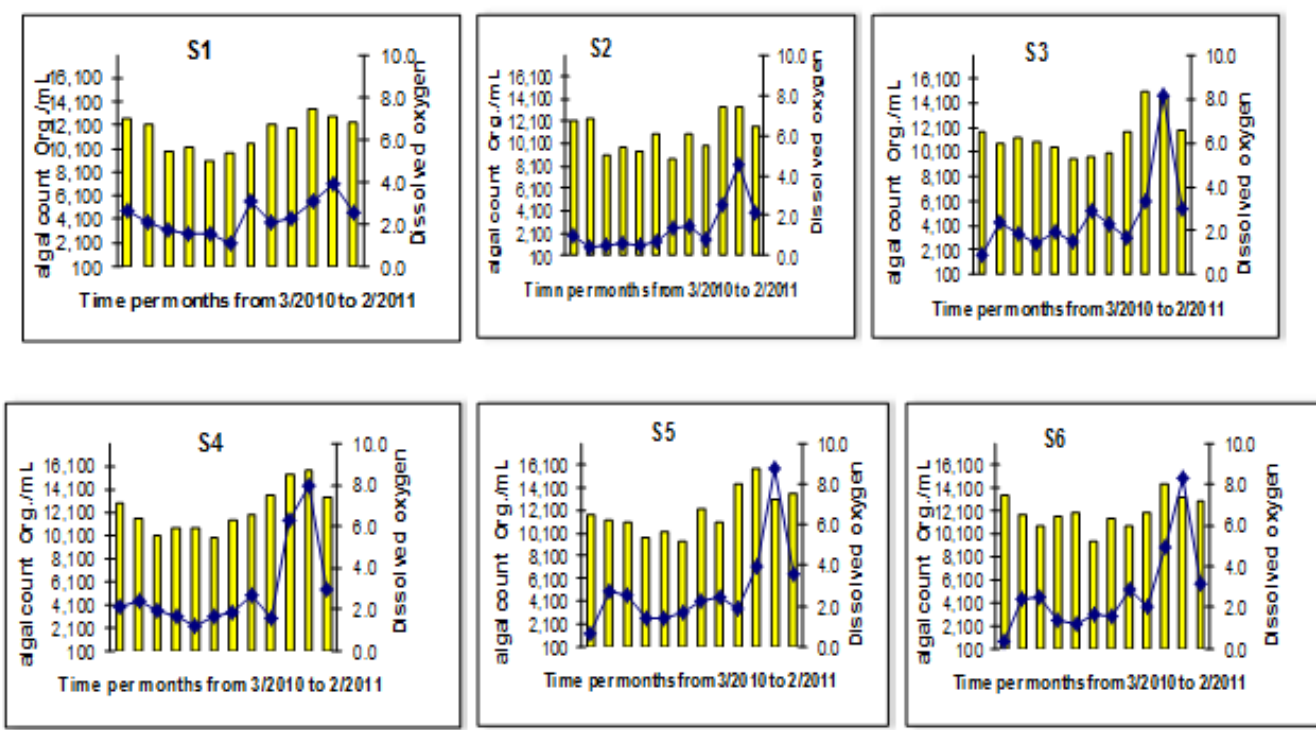

Fig. 4: Relationship between $\checkmark$ total algal count $(\mathrm{Org} / \mathrm{ml})$ and Oxygen along River Nile

Nitrogen content: Nitrates, nitrites, ammonia, and organic nitrogen are nitrogen forms that occur in water. The results of nitrite showed low levels during the whole period of investigation. This might be attributed to the fast conversion of $\mathrm{NO}_{2}^{-}$to $\mathrm{NO}_{3}{ }^{-}$ions by nitrifying bacteria (Abdo, 2004). Nitrate values ranged between 0.11 and $1.26 \mathrm{mg} \mathrm{L}^{-1}$ during the study period (Table1). The relation between nitrate and total algal counts was very clear where the minimum level of nitrate corresponded by maximum values of algal counts (Fig.5). The decrease in nitrate concentrations in spring and summer months at studded sites might be 
attributed to the uptake of nitrate by natural phytoplankton and its reduction by denitrifying bacteria (Sabae and Abdel-Satar, 2001). The increase in nitrate during cold months might be attributed to low consumption by phytoplankton as well as the oxidation of ammonia by nitrifying bacteria and biological nitrification (Abdo, 2013). Nitrates showed negative correlation with phytoplankton counts $(\mathrm{r}=-0.333)$.
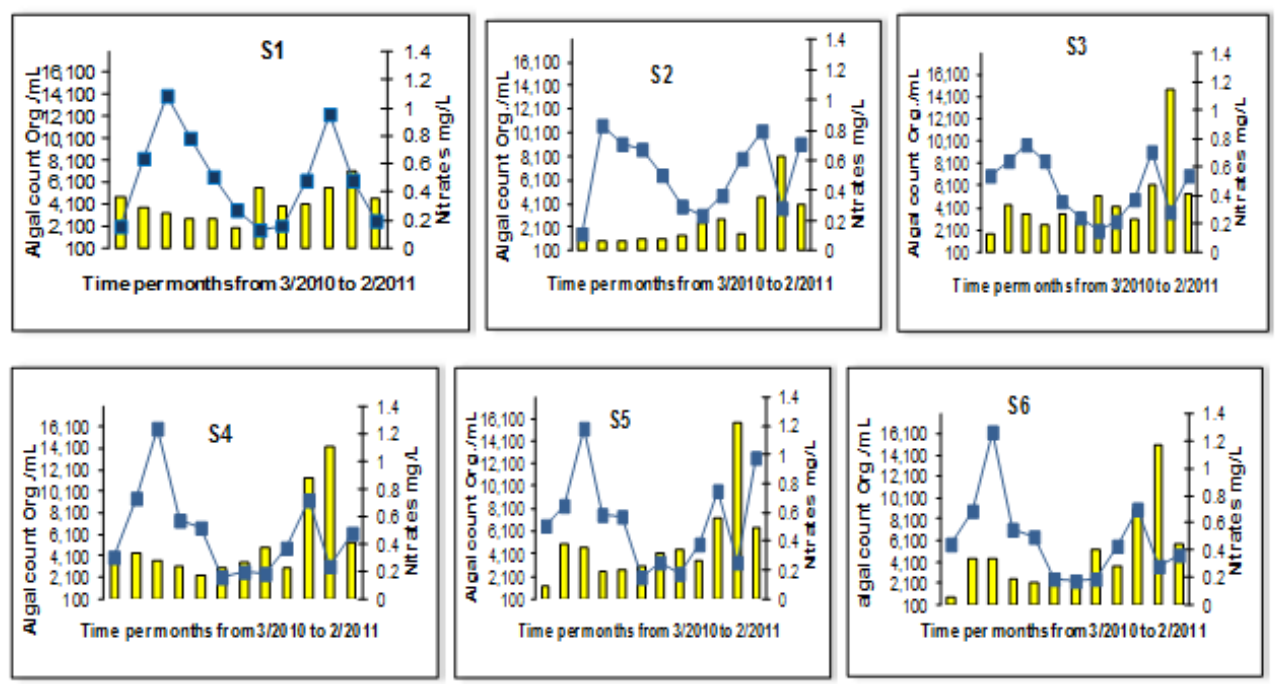

Fig. 5: Relationship between

total algal count $($ Org/ml $)$ and along River Nile

Phosphate: Phosphorus is available in the form of phosphate $\left(\mathrm{PO}_{4}-\mathrm{P}\right)$ in natural waters and generally occurs in low to moderate concentration (Stickney, 2005). The maximum phosphate concentration of $0.12 \mathrm{mg} \mathrm{L}^{-1}$ was recorded at $\mathrm{S}_{\mathrm{VI}}$ and minimum value of $0.01 \mathrm{mg} \mathrm{L}^{-1}$ at $\mathrm{S}_{\mathrm{I}}$ and $\mathrm{S}_{\mathrm{II}}$ (Table1). Statistical analysis in Table 2 showed negative correlation between phosphate and $\mathrm{pH}(\mathrm{r}=-0.656)$. The same results recorded by Abdel-Satar (2005) showed negative correlation between $\mathrm{pH}$ and ortho-P as well as total-P, suggesting that the solubility of phosphorus is dependent on $\mathrm{pH}$. 
Silica: Dissolved silica is an important nutrient for formation the silica wall of diatoms (dominate phytoplankton assemblages). During the study period silica values ranged from 1.36 to $14.26 \mathrm{mg} \mathrm{L}^{-1}$. The lowest values were associated with maximal growth of phytoplanktonic diatoms at all sites in summer months. The dissolved silica in Nile water showed negative correlation with algal counts $(\mathrm{r}$ $=-0.685), \mathrm{pH}(\mathrm{r}=-0.502)$ and nitrate $(\mathrm{r}=-0.069)$ and positive correlation with temperature $(\mathrm{r}=+0.872)$ (Table 2$)$ which agreed with (Shehata and Badr, 2010).

Microelements: Fe and $\mathrm{Mn}$ were investigated duri/ng the study and generally showed little amounts; also the results obtained reflect a positive correlation between $\mathrm{Fe}$ and $\mathrm{Mn}$ during most months indicated that the association of two elements originates from a common source during transportation and/or depositional reactions. These results agree with that reported by Abdel-Satar (2008) revealing that the concentrations of these elements are dependent on each other.

\section{Biological analysis}

A total of 83 algal species belonging to the five main algal groups, of which 1 species belonging to Eugleophyta, 2 species to Dinophyta , 11 species to Cyanophyta, 33 species to Bacillariophyta and 36 species to Chlorophyta. A maximum numbers of 69 and 67 species of phytoplankton were recorded at $S_{\text {III }}$ and $S_{\mathrm{VI}}$ respectively, which obtained the highest value of the nutrients content. However $S_{\mathrm{V}}$ showed the least number of species (61). Although $S_{\text {IV }}$ had the maximum individual number of phytoplankton (5227 Org.ml ${ }^{-1}$ ) it attained a relatively low number of species (64 species, Table 3 ). The total algae number ranged from 2597 to $5227 \mathrm{Org}$. $\mathrm{ml}^{-1}$ with a maximum attained during winter months where diatom was the dominant group. Cyanophyta ranged between 456 and $1184 \mathrm{Org}$. $\mathrm{ml}^{-1}$, for Chlorophyta ranged between 734 and 1484, Euglenophyta ranged from 1 to 4 , Dinophyta ranged between 10 and 24 while Bacillariophyta

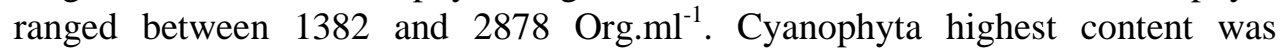
recorded at $S_{\mathrm{I}}$ and $S_{\mathrm{V}}$ may be due to the high temperature values and also nutrient content, while the highest count of Chlorophyta was recorded at $\mathrm{S}_{\mathrm{III}}$. The highest diatom count was recorded at $\mathrm{S}_{\mathrm{IV}}$ where the lowest silica content (Fig.6). 
Table3. Annual variations in cell number of total phytoplankton at six sites.

\begin{tabular}{|c|c|c|c|c|c|c|c|c|c|c|c|c|}
\hline \multirow{2}{*}{ Dites } & \multicolumn{2}{|c|}{ Site I } & \multicolumn{2}{|c|}{ Site II } & \multicolumn{2}{|c|}{ Site III } & \multicolumn{2}{|c|}{ Site IV } & \multicolumn{2}{|c|}{ Site V } & \multicolumn{2}{|c|}{ Site VI } \\
\hline & 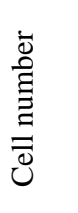 & 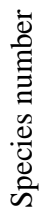 & 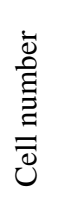 & 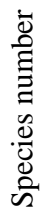 & 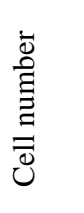 & 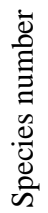 & 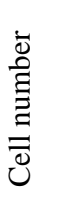 & 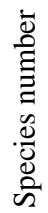 & 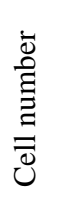 & 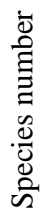 & $\begin{array}{l}\dot{\bar{D}} \\
\text { 志 } \\
\bar{\Xi} \\
\overline{\bar{U}}\end{array}$ & 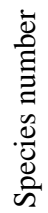 \\
\hline Cyanophyta & 1184 & 9 & 456 & 8 & 874 & 8 & 910 & 7 & 865 & 9 & 781 & 8 \\
\hline Chlorophyta & 1265 & 29 & 734 & 29 & 1360 & 32 & 1419 & 30 & 1484 & 29 & 1367 & 31 \\
\hline Euglenophyta & 4 & 1 & 1 & 1 & 2 & 1 & 3 & 1 & 2 & 1 & 2 & 1 \\
\hline Dinophyta & 12 & 2 & 24 & 2 & 20 & 2 & 17 & 2 & 17 & 2 & 10 & 2 \\
\hline Bacillariophyta & 1651 & 25 & $\begin{array}{c}138 \\
2\end{array}$ & 26 & 2525 & 26 & 2878 & 24 & 2682 & 20 & 2804 & 25 \\
\hline Total & 4116 & 66 & 259 & 65 & 4781 & 69 & 5227 & 64 & 5050 & 61 & 4964 & 67 \\
\hline Diversity & 1.5 & & 1.35 & & 1.36 & & 1.56 & & 1.51 & & 1.51 & \\
\hline
\end{tabular}
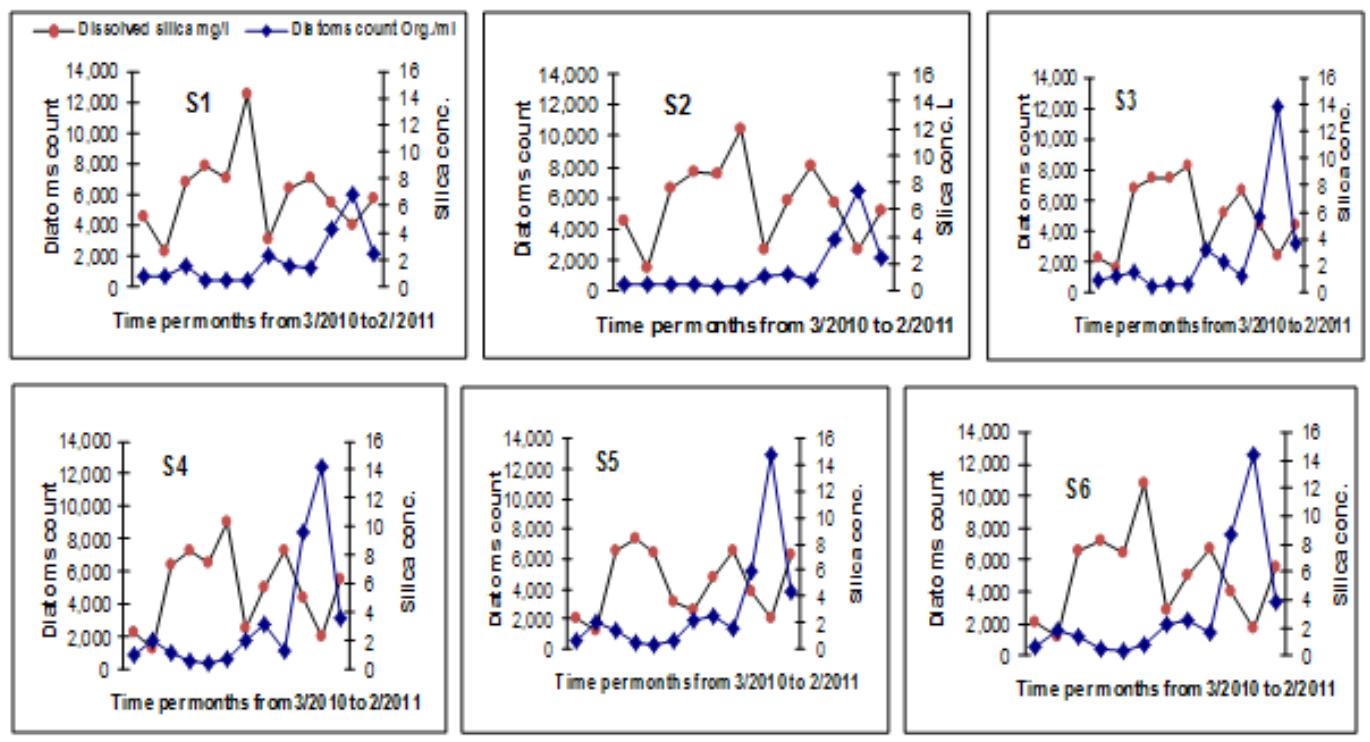

Fig.6: Relationship between Diatoms count (Org./ml ) and dissolved silica along River Nile. 
The variations of temperature are found to affect the periodicity diversity and succession of the phytoplankton group (EL-sheekh et al., 2010). The vigorous growth of Cyanophyta is correlated with the increase of phosphorus of surface water, whereas, silica depletion leads to a replacement of the large diatoms by large Cyanophyta (Deyab et al., 2002).

The main value of diversity index among the different sites ranged from 1.17 at $S_{\text {I }}$ (because of the relatively high movement of water) to 1.36 at $S_{\text {II }}$ (may be due to the presence of an island). This range indicates that, this area is moderately polluted.

According to the frequency of abundance (Table 4) of Cyanophyta, Microcystis flos-aquae, Merismopedia elegans and Dactylocoleobsisrhaphidioides were the most dominant species within the different sites. Cyanophyta often dominate the fresh-water phytoplankton community in surface waters, particularly in eutrophic system and are major producers of toxins as well as taste and odor compounds (Codd $\boldsymbol{e t}$ al., 1989). The abundance of Microcystis at the all studded sites during whole period of the study, it can be linked to the work of Sa'ad and Antane (1978) who showed that low value of $\mathrm{N}$ and $\mathrm{P}$ increases the growth of Microcystis spp.

The most frequent species of Chlorophyta which recorded within the different sites were Chlamydomonas ehrenbergi, Botryococcus braunil, Dictyoshaerium puluchellum, Ankistrodesmus falcatus and Scenedesmus armatus. Among the diatoms, Stephanodiscus hantzschii, Cyclotella ocellata, Melosira granulate, Nitzschia holsatica, Diatoma elongatum and Syndra ulna were the most dominant throughout the year at different sites (Table 4). In general terms, the diatoms found are characteristic of eutrophic water bodies and most are recorded as halophytic which preferring alkaline waters (Wolf, 1982; Shehata $\boldsymbol{e t}$ al., 2009) which correspond to the conditions of relative high $\mathrm{pH}$ in the River Nile. 
Table 4. Annual variations in frequency of different taxa at different sites at the studied area.

\begin{tabular}{|c|c|c|c|c|c|c|c|}
\hline Species & Site I & Site II & Site III & Site IV & Site V & Site VI & T.F \\
\hline \multicolumn{8}{|l|}{ Cyanophyta } \\
\hline Anabaena constrica & 1 & 1 & 2 & 2 & 1 & 1 & 8 \\
\hline Chrococcus turgidus & 1 & 1 & 1 & 1 & 1 & 1 & 6 \\
\hline $\begin{array}{l}\text { Coelosphaerium } \\
\text { kuetzingellanum }\end{array}$ & 1 & -- & --- & -- & -- & ---- & 1 \\
\hline $\begin{array}{l}\text { Dactylocoleobsis- } \\
\text { Irregularis }\end{array}$ & 1 & 1 & 1 & 1 & 1 & 1 & 6 \\
\hline $\begin{array}{l}\text { Dactylocoleobsis- } \\
\text { rhaphidioides }\end{array}$ & 5 & 5 & 3 & 6 & 6 & 8 & 33 \\
\hline $\begin{array}{l}\text { Gomphosphaerium } \\
\text { naegellana }\end{array}$ & 2 & 1 & 1 & 3 & 2 & 1 & 10 \\
\hline Merismopedia elegans & 3 & 3 & 3 & 4 & 4 & 3 & 20 \\
\hline Microcystis flos-aquae & 362 & 135 & 270 & 273 & 254 & 277 & 1571 \\
\hline Nostoc linckia & ------ & 6 & -- & --- & --- & -- & 6 \\
\hline Oscillatoria princeps & ---- & --- & -- & -- & 1 & 1 & 2 \\
\hline Spirulina abbreviate & 1 & & 1 & & 1 & -- & 3 \\
\hline \multicolumn{8}{|l|}{ Chlorophyta } \\
\hline Ankistrodesmus falcatus & 7 & 5 & 8 & 10 & 9 & 9 & 48 \\
\hline Actinastrum hantzschili & 3 & 2 & 4 & 4 & 4 & 4 & 21 \\
\hline Botryococcus braunii & 23 & 12 & 31 & 30 & 25 & 36 & 157 \\
\hline $\begin{array}{l}\text { Chlamydomonas } \\
\text { ehrenbergi }\end{array}$ & 312 & 183 & 334 & 341 & 349 & 304 & 1823 \\
\hline Chlorella vulgaris & ---- & --- & 1 & --- & ---- & --- & 1 \\
\hline Chodatella cillate & 1 & 1 & 1 & 2 & 1 & 2 & 8 \\
\hline Closterium pronum & 3 & 1 & 2 & 3 & 3 & 5 & 17 \\
\hline Coelastrum microporum & 2 & 1 & 2 & 2 & 2 & 2 & 11 \\
\hline
\end{tabular}

Egyptian J. of Phycol. Vol. 16, 2015 


\begin{tabular}{|c|c|c|c|c|c|c|c|}
\hline \multicolumn{8}{|c|}{ Table 4. (Cont'd.). } \\
\hline Species & Site I & Site II & Site III & Site IV & Site V & Site VI & T.F \\
\hline Cosmarium granatum & ---- & --- & --- & 1 & 1 & 1 & 3 \\
\hline $\begin{array}{l}\text { Cosmerium } \\
\text { praemorsum }\end{array}$ & --- & --- & 1 & --- & --- & --- & 5 \\
\hline Crucigenia apiculata & 8 & 4 & 9 & 5 & 7 & 6 & 39 \\
\hline $\begin{array}{l}\text { Dictyosphaerium } \\
\text { puluchellum }\end{array}$ & 5 & 4 & 13 & 13 & 13 & 13 & 61 \\
\hline Eudorina elegans & 1 & --- & 1 & 1 & 1 & 1 & 5 \\
\hline Golenkinia radiate & 2 & 2 & 2 & 2 & 1 & 2 & 11 \\
\hline $\begin{array}{l}\text { Haematococcus } \\
\text { pluvialis }\end{array}$ & 1 & 1 & 1 & 1 & 1 & 1 & 6 \\
\hline Kirchenriella obese & 1 & 1 & 1 & 2 & 1 & 2 & 8 \\
\hline Micractinium pasillum & 3 & 2 & 3 & 4 & 5 & 4 & 21 \\
\hline Mougeotia scalaris & --- & --- & --- & --- & --- & 1 & 1 \\
\hline $\begin{array}{l}\text { Nephrocytium } \\
\text { agardhlanum }\end{array}$ & 1 & 1 & 2 & 2 & 2 & 2 & 10 \\
\hline Oocystis lactularis & 1 & 1 & 1 & -- & ---- & --- & 3 \\
\hline Oocystis parva & 3 & 3 & 5 & 4 & 6 & 5 & 26 \\
\hline Oocystis soltaria & 1 & 1 & 2 & 2 & 1 & 2 & 9 \\
\hline Pandorina morum & --- & ---- & ---- & 1 & ---- & --- & 1 \\
\hline Pediastrum angulosum & 2 & 1 & 2 & 2 & 2 & 2 & 11 \\
\hline Pediastrum gracillimum & 1 & 1 & 1 & 1 & 1 & 1 & 6 \\
\hline Pediastrum tetras & 1 & -- & 1 & -- & -- & --- & 2 \\
\hline $\begin{array}{l}\text { Scenedesmus } \\
\text { acuminatus }\end{array}$ & 2 & 1 & 1 & 2 & 2 & 1 & 9 \\
\hline Scenedesmus acutus & 2 & 2 & 2 & 2 & 2 & 3 & 13 \\
\hline Scenedesmus armatus & 5 & 7 & 8 & 8 & 7 & 8 & 43 \\
\hline Scenedesmus obllquus & -- & 1 & 1 & 1 & 1 & 1 & 5 \\
\hline
\end{tabular}

Egyptian J. of Phycol. Vol. 16, 2015

- 14 - 


\begin{tabular}{|c|c|c|c|c|c|c|c|}
\hline \multicolumn{8}{|c|}{ Table 4. (Cont'd.). } \\
\hline Species & Site I & Site II & Site III & Site IV & Site V & Site VI & T.F \\
\hline Scenedesmus patydiscus & 1 & 1 & -- & -- & -- & 1 & 3 \\
\hline Selenastrum gracile & 1 & 2 & 1 & 2 & 1 & 1 & 8 \\
\hline Sphaerocystis schroeteri & --- & 1 & 1 & 1 & 1 & 1 & 5 \\
\hline Staurastrum paradoxum & 2 & 1 & 2 & 3 & 3 & 2 & 12 \\
\hline Tetraedron minimum & 2 & 3 & 2 & 1 & 3 & 2 & 13 \\
\hline Ulothrix subitllssima & 2 & 1 & 2 & 4 & 2 & 3 & 14 \\
\hline \multicolumn{8}{|l|}{ Euglenophyta } \\
\hline Trachelomonas armata & 1 & 1 & 1 & 1 & 1 & 1 & 6 \\
\hline \multicolumn{8}{|l|}{ Dinophyta } \\
\hline Ceratium hirundinella & 1 & 1 & 1 & 2 & 2 & 1 & 8 \\
\hline Peridinium tabulatum & 3 & 8 & 5 & 4 & 3 & 3 & 26 \\
\hline \multicolumn{8}{|l|}{ Bacillariophyta } \\
\hline Amphipleura pellucida & --- & 1 & 1 & --- & --- & --- & 2 \\
\hline Amphora Ovalis & 1 & 1 & 1 & 1 & 1 & 1 & 6 \\
\hline Asterionella formosa & 1 & 1 & --- & 1 & ---- & --- & 3 \\
\hline $\begin{array}{l}\text { Caloneis } \\
\text { amphisbaena }\end{array}$ & --- & 1 & --- & --- & --- & 1 & 2 \\
\hline Cocconneis pediculus & 8 & 5 & 6 & 8 & 7 & 8 & 42 \\
\hline Cocconneis scutellm & 1 & 1 & 1 & & & & 3 \\
\hline Cyclotella ocellata & 68 & 87 & 94 & 110 & 98 & 101 & 558 \\
\hline Cymatopleura solea & 1 & --- & 1 & --- & ---- & 1 & 3 \\
\hline Cymbella tumida & 2 & 3 & 1 & 2 & 3 & 1 & 12 \\
\hline Diatoma elongate & 13 & 14 & 20 & 24 & 22 & 21 & 114 \\
\hline Diatoma hiemale & 1 & 2 & 1 & 2 & 1 & 1 & 8 \\
\hline
\end{tabular}


Table 4. (Cont'd.).

\begin{tabular}{|c|c|c|c|c|c|c|c|}
\hline Species & Site I & Site II & Site III & Site IV & Site V & Site VI & T.F \\
\hline Fragilaria capucina & 1 & 1 & 1 & 1 & 1 & 1 & 6 \\
\hline Fragilaria crotonensis & 1 & 1 & 1 & 1 & 1 & & 5 \\
\hline Fragilaria leptostauron & 1 & 1 & 1 & 1 & 1 & 1 & 6 \\
\hline Fragilaria pinnata & 2 & 1 & 1 & 1 & 1 & 1 & 7 \\
\hline $\begin{array}{l}\text { Gomphonema } \\
\text { acuminatum }\end{array}$ & --- & 1 & 1 & 1 & --- & --- & 3 \\
\hline $\begin{array}{l}\text { Gomphonema } \\
\text { olivaceum }\end{array}$ & 1 & 2 & 1 & 2 & 2 & 2 & 10 \\
\hline Gyrosigma kutzingii & --- & 1 & --- & --- & -- & 1 & 2 \\
\hline Melosira granulate & 59 & 53 & 100 & 82 & 81 & 78 & 453 \\
\hline Navicula cryptocephala & 3 & 3 & 3 & 4 & 4 & 3 & 20 \\
\hline Navicula cuspidata & ---- & --- & 1 & --- & --- & 1 & 2 \\
\hline Navicula pygmaea & --- & --- & --- & --- & 1 & --- & 1 \\
\hline Nitzschia hiemalis & --- & --- & 1 & --- & -- & --- & 1 \\
\hline Nitzschia holsatica & 14 & 10 & 21 & 32 & 24 & 26 & 127 \\
\hline Nitzschia linearis & 11 & 9 & 14 & 20 & 16 & 15 & 85 \\
\hline Nitzschia paradoxa & 1 & -- & --- & --- & --- & -- & 1 \\
\hline Nitzschia sigmoedea & 1 & 1 & 1 & 1 & 1 & 1 & 6 \\
\hline Pinnularia gibba & --- & --- & -- & 1 & --- & 1 & 2 \\
\hline $\begin{array}{l}\text { Stephanodiscus } \\
\text { hantzschii }\end{array}$ & 308 & 234 & 524 & 588 & 521 & 553 & 2728 \\
\hline Surirella robusta & 1 & 1 & 1 & 1 & -- & 1 & 5 \\
\hline Syndra acus & 1 & --- & --- & 1 & --- & 1 & 3 \\
\hline Syndra ulna & 11 & 11 & 21 & 22 & 16 & 19 & 100 \\
\hline Syndra Vaucheriae & 2 & 1 & 1 & 2 & 1 & 1 & 8 \\
\hline
\end{tabular}




\section{Chlorophyll "a" content:}

The concentration of Chl.a ranged from 2.31 to $26.05 \mu \mathrm{g} \mathrm{L}{ }^{-1}$ (Fig.7). The highest value of Chl.a was detected during winter months at all sites due to the most common filamentous forms with high Chl.a content especially those belonging to diatoms, namely, Melosira granulate, which contain high Chl.a content. However, good relationship between phytoplankton and Chl.a content were established indicating that physiological state of River Nile phytoplanktonic algae is in good condition. This agreement with the results obtained by Shehata $\boldsymbol{e t}$ al., 2009 found Chl.a content ranged from 11.7 to $52.7 \mu \mathrm{g} \mathrm{L}^{-1}$ for River Nile water. However the highest value of Chl.a was detected during winter season. Havens (1994) reported that, the maximum Chl.a concentration was more $40 \mathrm{mg}$ $\mathrm{L}^{-1}$ at eutrophic Lake at Florida and he found a good relation between chlorophyll a concentration and algal bloom frequencies. Statistical analysis showed that positive correlation of Chl.a with total algal counts $(\mathrm{r}=+0.953), \mathrm{pH}(\mathrm{r}=+0.883)$ and turbidity $(\mathrm{r}=+0.612)$.
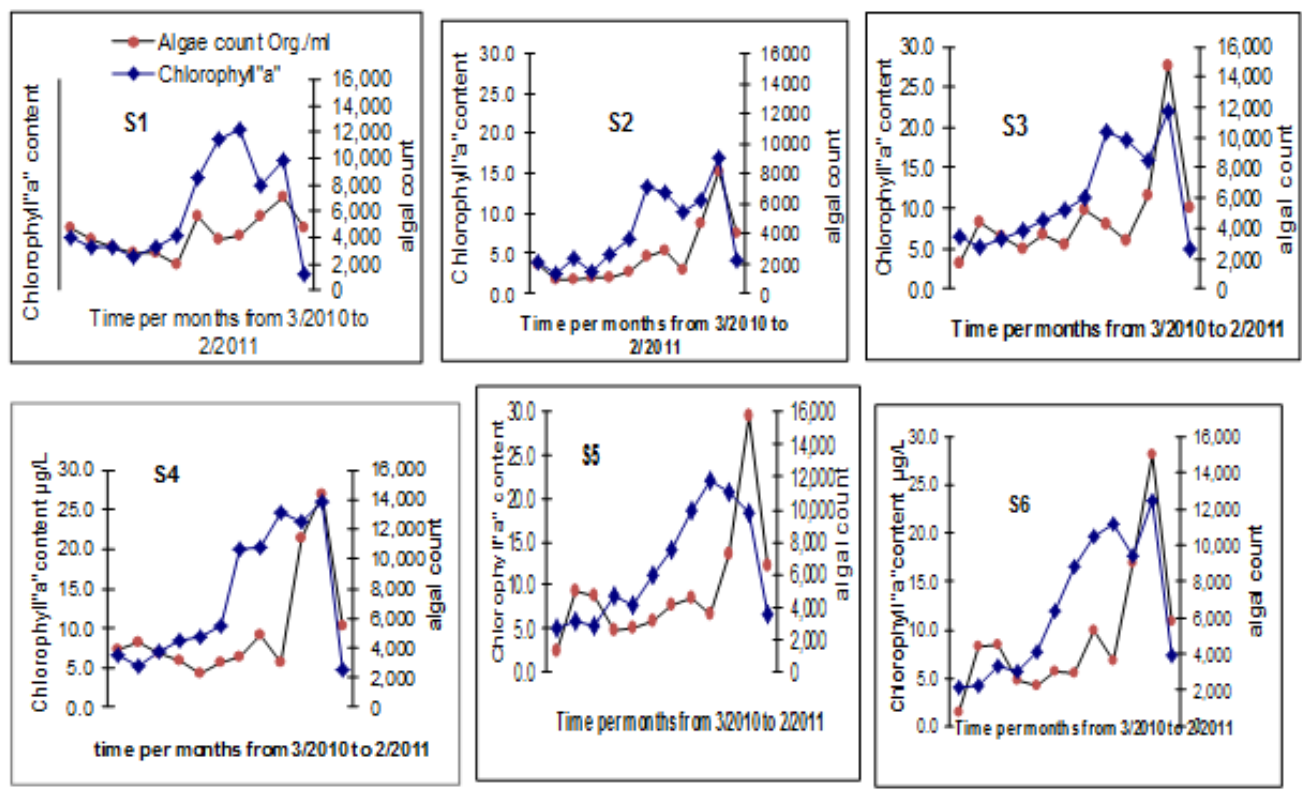

Fig.7: Relationship between Chlorophyll "a" content and total algal count along

\section{River Nile.}

Egyptian J. of Phycol. Vol. 16, 2015 


\section{Conclusion}

The most of the water samples were below or out of limited according to the WHO standards. In general the River Nile water quality was satisfactory and suitable for human consumption and other domestic uses. The total algal counts of the River Nile has significantly changed during different months and increased at winter months. Account of algae in surface water samples is a necessary part of water quality monitoring. Algal counts are more consistent to expect the type of drinking water treatment steps for overcoming the planktonic algae.

\section{Recommendations}

Regular monitoring of phytoplankton in drinking water sources is necessary to considerate the development of phytoplankton populations structure ,the status of River Nile water quality and selection of water treatment schemes for overcoming Nile water algae.

\section{References}

Abd El-Hady, H.H. (2014). Alternations in biochemical structures of phytoplankton in Aswan Reservoir and River Nile, Egypt. Journal of Biodiversity and Environmental Sciences, 4(2) :68-80.

Abdel-Hamid, M.I.; Shaaban-Dessouki, S. A. and Skulberg, O. M. (1992). Water quality of the River Nile in Egypt. 1. Physical and chemical characteristics. Archiv für Hydrobiologie, Supplement, 90 (3): 283-310.

Abdel-Satar, A.M. (2005). Water quality assessment of River Nile from Idfo to Cairo. Egyption Journal of aquatic Research, 31(2): 200-223.

Abdel-Satar A.M. (2008). Chemistry of major ions, nutrient salts and heavy metals in Lake Manzalah, Egypt. Egyption Journal of aquatic Research, 34(2): 130 - 148.

Abdo, M.H. (2004). Environmental studies on the River Nile at Damietta branch region, Egypt. Journal of Egyptian Academic Society for Environmental Development (D-Environmental Studies), 5(2): 85-104.

Abdo, M.H. (2013). Physico- chemeical studies on the pollutants effect in the aquatic environment of Rosetta branch River Nile, Egypt. Life Science Journal, 10 (4): 493-501. 
Abo El-lil, A.H. (2003): Evaluation the ecological impacts due to unique torrent phenomenon on aquatic ecosystem (River Nile, Cairo, Egypt). Journal of Biological Sciences, 3 (2): 197-203.

Amer, A.S. and Abd El-Gawad, H.A. (2012). Rapid Bio-indicators assessment of macrobiotic pollution on aquatic environment. International water technology journal, 2(3): 196- 205.

American Public Health Association, (2005). Standard methods for the examination of water and wastewater. APHA, AWWA, WPCE, N. Y. Washington.

American Public Health Association, (1992).Standard methods for the examination of water, sewage and waste water .APHA, 18th Edition.

Challerjee, S. and Machler, M. (1995). Robust regression: a weighted least squares approach, communications in statistics, Theory and Methods, 26: 1381-1394.

Codd, G.A.; Bell, S.G. and Brooks, W.P. (1989). Cyanobacterial toxins in water. Water Science Technology, 21: 1-13.

Deyab, M.A.; Nemat Alla, M.M. and El-Adl, F.M. (2002). Phytoplankton diversity in some ponds at New Damietta - Egypt. Egyptian Journal of Phycology, 3: 1-15.

El-Sheekh, M.M.; Deyab, M.A.I.; Desouki, S.S. and Eladl, M. (2010). Phytoplankton compositions as a response of water quality in El Salam Canal Hadous drain and Damietta branch of River Nile, Egypt. Pakistan Journal of Botany, 42(4): 2621-2633

Fishar, M.R.A. and Khalifa, U.S.A. (2003). Status of biodiversity of River Nile, Workshop hold at British Council, 9 December, Cairo, Egypt. 80 pp.

Gales, M. E, Julianand jr. E. C. and Kroner, R. C. (1966). Methods for quantitative determination of total phosphorus in water. J. AWWA, 56: 1363-1368.

Garret, M.K.; Weatherap, S.T.C. and Allan, M.D.B. (1970). Algal culture in a liquid phase of animal slurry. Effect of light and temperature upon growth and phosphorus removal. Environmental Pollution, 15: 141-154.

Gharib, S.M. and Abdel-Halim A.M. (2006). Spatial variation of phytoplankton and some physico-chemical variables during the highest flood season in 
Lake Nasser (Egypt). Egyptian Journal of Aquatic Research, 32 (1): 246263.

Hammad, D.M. and Ibrahim, L.A. (2012). Influence of iron and silicon speciation on the abundance of diatoms in River Nile. Journal of Applied Sciences Research, 8(1): 556-570.

Hassan, K.Y.; Kutama, A.S. and Ibrahim, Y. (2010). Algal diversity in relation to physico-chemical parameters of three ponds in Kano metropolis, Nigeria. Bioscience Research Communications, 22 (6): 321-328.

Havens, K.E. (1994). Relationships of annual chlorophyll a means, maxima, and algal bloom frequencies in a shallow eutrophic lake (Lake o keechobee, Florida, USA). Lake Reserve. Manage., 10(2):133-138.

Hindak, F.M.; Komarek, J.; Marvan P. and Ruzicka, J. (1975). Kluc Na Urcovanic Vytrousnych Rastlin, I. Diol. Riasy.

Lai, P.C.C. and Lam P.K.S. (1997). Major pathways for nitrogen removal in wastewater stabilization ponds. Water, Air and Soil pollution, 94: 125136.

Mohammed, A.A.; Ahmed, A.M. and Mohammed, Z.A. (1986). Studies on phytoplankton of the Nile Upper Egypt. Limnologica (Berlin) 17 (1): 99117.

National Water Research Centre (NWRC), WL/DELFT Hydraulics (2000). "National water resources plan for Egypt, water quality and pollution control". Technical Report No. 5.

Sa'ad, A.H. and Antane, S.E. (1978). Limnologicl studies on the River Tigri, Iraq I. Environmental Health Engineering in the tropics Longman group Limited, London pp. 27

Sabae, S.Z. and Abdel-Satar, A.M. (2001). Chemical and Bacteriological studies on El-Salam Canal, Egypt. J. Egyptian Academic Society Environmental Development, 2(1): 173-197.

Shannon, C. E. and Weaver, W. (1963). The mathematical theory of communication. Univ. of Illinois Press, Urbana, 117 p.

Sharma, S.; Dixit, S. and Jain, P. (2008). Statistical evaluation of hydrobiological parameters of Narmada River water at Hoshangabad City, India. Environmental Monitoring and Assessment, 143: 195-202. 
Shehata, S.A. and Badr, S.A. (2010). Water quality changes in River Nile Cairo, Egypt. Journal of Applied Sciences Research, 6 (9): 1457-1465.

Shehata S.A.; Badr, S.A.; Ali, G.H.; Ghazy, M.M.; Moawad, A.K. and Wahba, S.Z. (2009). Assessment of Nile water quality via phytoplankton changes and toxicity bioassay test. Journal of Applied Sciences Research, 5(12): 2083-2095.

Stickney, R.R. (2005). Aquaculture. An Introductory text. CABI Publishing, UK.p265.

WHO (2004). World Health Organization. WHO Guidelines for Drinking water Quality vol. 2 Health criteria and other supporting information. Geneva (In press).

Wolf, H. (1982). Methods of coding of ecological data from diatoms for computer utilization. Rijks Geologishe Dienst: Mededelinge. 36(2): 95-11

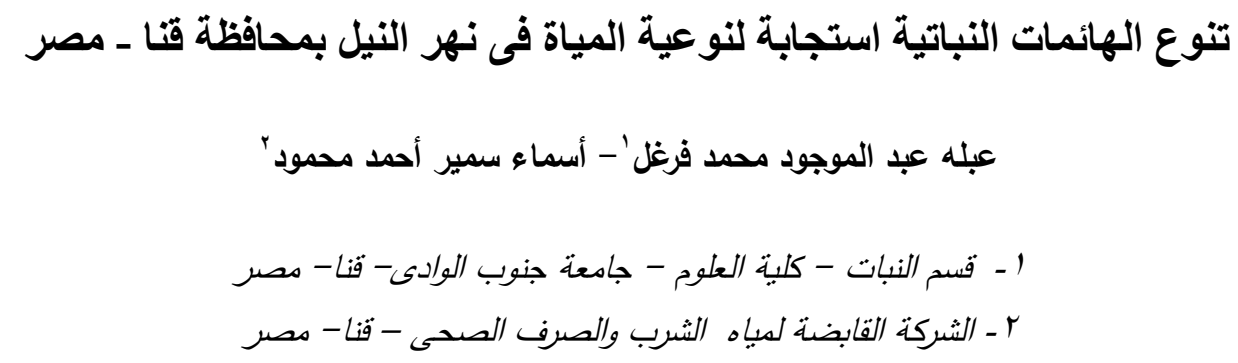

بهدف البحث الى متابعة التغيرات في كثافة الفيتوبلانكتون (الهائمات النبانية) وعلاقتها بالخواص الفيزيائية والكيميائية لمياه نهر النيل في الفترة من مارس 2010الى فبراير 2011 في ست مواقع بطول نهر

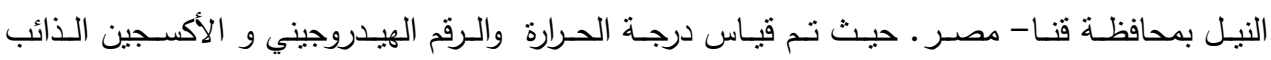
والأكسجين المستهلك كيميائيا والعكارة والمواد المغذية (المغذيات). فى هذه الدراسة تم تسجيل 83 نوعاً من الفيتوبلانكتون تتنمى الى خمسـة اقسام من الطحالب منها 36 نوع تتبع مجموعة الطحالب الخضراء حيث كانت المجموعة السائدة خلال فترة الدراسة و 33 نوع تتبع مجموعة الدياتومات و 11 نوع تتبع مجموعة الطحالب الخضـراء المزرقـة و نـوعين للدينوفيتا (الطحالب السـوطيه الدواره) ونوعـاً واحداً يتبع الطحالب اليوجلينية. تراوح العدد الكلى للطحالب ما بين 2597 الى 5227 طحلب / ميللى لتر ـ أما بالنسبة لتركيز 
الكلوروفيل أ والذى يعتبر دليل على نـو الطحالب فقد تراوح مـا بين 26.05 الى 2.31 ميكروجرام/ لتر .التحليل الاحصائى أظهر علاقة ايجابية بين العدد الكلى للطحالب وكلا من الرقم الهيدروجيني والعالئ العكارة

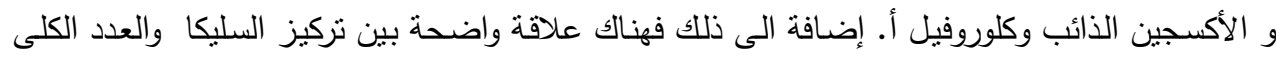
للاياتومات. 